\title{
Evaluating the effects of layered soils on water flow, solute transport, and crop growth with a coupled agro-eco-hydrological model
}

\author{
Shuai Chen ${ }^{1} \cdot$ Xiaomin Mao ${ }^{1} \cdot$ Manoj K. Shukla ${ }^{2}$ \\ Received: 13 November 2019 / Accepted: 22 April 2020 / Published online: 30 May 2020 \\ (C) The Author(s) 2020
}

\begin{abstract}
Purpose Soil salinization and degradation in the arid and semiarid areas are a worldwide phenomenon. Soil capping with capillary barriers is a potential practice to hydraulically isolate contaminated soils, which may improve the soil environment for plant growth. This study aims to investigate the influences of soil capping on crop growth and soil salinization control in the arid area with shallow groundwater tables.

Materials and methods A one-dimensional agro-eco-hydrological model, LAWSTAC, capable of simulating water and solute transport in layered soil coupled with crop growth, was applied for simulating sunflower growth under field condition in Arid Northwest China. The model was calibrated and validated with the experimental data of 2012 and 2013 crop seasons. The calibrated model was then used to explore how the soil capping consisting of combinations of fine soil $(10,15,17,19$, and $20 \mathrm{~cm}$ thick) and coarse sand (10,5,3,1, and $0 \mathrm{~cm}$ thick correspondingly) would influence the soil water and salt dynamics, and seed yield.

Results and discussion Simulation results by LAWSTAC compared well with the observed soil water content, salt concentration, leaf area index, and seed yield. Further scenario simulations showed that a sand layer in the soil capping could greatly affect the water and salt distribution in the soil above and below the sand layer. Though soil capping could decrease the water storage (WS) in the root zone, it caused no obvious increase in water stress to root uptake for sand thickness of $1-3 \mathrm{~cm}$ and also considerably reduced the root zone salt content (SC) in crop season compared with that without soil capping. The average WS during the crop season showed a negative correlation with the thickness of sand layer in the soil capping. The average SC from planting to harvest was significantly lower for thicker sand in the soil capping. To soils with high background salinization, the increase of sand thickness would be helpful for enhancing seed yield, until it reached a critical value.

Conclusions Coarse soil layer in the soil capping could prevent salt moving into the root zone, while fine soil could supply water to plant once water in coarse soil was low. Thus, in a long run, the soil capping consisting of combinations of fine and coarse soils with certain thicknesses would be an alternative practice for saline soil reclamation and improving crop production in arid area with shallow groundwater tables and soil salinization.
\end{abstract}

Keywords Layered soil $\cdot$ Water and salt dynamics $\cdot$ Crop growth $\cdot$ Agro-ego-hydrologic model

Responsible editor: Yi Jun Xu

Xiaomin Mao

maoxiaomin@cau.edu.cn

Shuai Chen

slsdchen@163.com

Manoj K. Shukla

shuklamk@nmsu.edu

1 College of Water Resources \& Civil Engineering, China Agricultural University, Beijing 100083, People's Republic of China

2 Department of Plant and Environmental Sciences, New Mexico State University, MSC 3Q, P.O. Box 30003, Las Cruces, NM 88003-8003, USA

\section{Introduction}

Water shortage and soil salinity are major concerns for agricultural development in the arid and semiarid regions of the world (Askri et al. 2014; Ghamarnia and Jalili 2014). High evaporation and shortage of freshwater resources exacerbate soil salinization in these areas (Xu et al. 2013; Mora et al. 2017). On average, more than $30 \%$ of the irrigation lands in the arid and semiarid regions are affected by salts (Asfaw et al. 2018), resulting in reduction of the crop production and economic income. Furthermore, salinity triggers the processes of soil particle dispersion and nutrient lose, which could turn the 
farmland to barren land. With the increasing population pressure and food demand, it is necessary to reclaim the salinized/ barren land to farmland for agricultural production under the background of water shortage (Metternicht and Zinck 2003).

Water and solute transport in layered soil greatly differs from the homogeneous one. Besides, research results showed that the textures, thicknesses, and locations of soil layers in vertical profile have distinct effects on water and salt dynamics in the crop root zone, and consequently on the crop productivity (He et al. 2013; Predelus et al. 2015). This influence not only presents on water flow but also on the soil water and salt storage (Ityel et al. 2011; Liu et al. 2019). Taking advantage of the different properties of soil layers, the technique of layering soil has been used in the crop root zone to save agricultural irrigation water and to alleviate soil salinization condition (Wehr et al. 2005; Ityel et al. 2012).

Field and lab experiments were conducted to show the effect of texturally distinct soil on water and solute dynamics, and crop production (Zettl et al. 2011; Cheng et al. 2013). The mechanisms can be attributed to the textural properties of the soil. When the water content is high, coarse-textured soils offer lower resistance to water and solute transport than finetextured soils. However, with soil drying, unsaturated hydraulic conductivity as well as hydraulic connectivity of coarsetextured soils decreases sharply turning it into a capillary barrier (Si et al. 2011). As a result, the presence of a fine-textured soil layer overlying a coarse-textured soil layer will improve the soil water storage in the upper soil due to the capillary barrier effect (Huang et al. 2011; Ityel et al. 2012), and the coarse interlayer soil could prevent upward salt migration into the topsoil (Rooney et al. 1998). Layering coarse- over finetextured soils can also in, crease the water storage when the hydraulic conductivity of the fine-textured soil is less than that of the overlying coarse soil. Therefore, the layered soil could favor vegetation establishment and increase crop yield under high evaporation and soil salinization condition (Ren and Huang 2016). However, field experiments reported so far were conducted under different experimental conditions, and reported results are hard to be generalized based on differences in texture, thickness, and location of soil horizons.

Numerical simulation can depict the detailed physical process and improve our understanding of the influence of soil layers on water and solute transport as well as the crop growth and yield (Chen et al. 2015; Lekakis and Antonopoulos 2015). Among the hydrologic models, HYDRUS (Simunek et al. 2005) and SWAP (van Dam et al. 1997) are two widely used models and have been applied to the arid area worldwide (Zhou et al. 2012; Xu et al. 2013), which could enhance the insights gained from the experimental studies. HYDRUS cannot evaluate crop yield response to agricultural managements. SWAP can simulate the crop growth, but due to the explicit central difference scheme, it cannot simulate solute transport well in some cases. To better understand water flow, solute transport, and crop response in farmlands, many studies have coupled the hydrologic and crop growth models. For example, Wang et al. (2017) coupled the HYDRUS-1D with the growth module of EPIC (Williams et al. 1989) to investigate the salt and water movement, and crop response to water deficit and salinity. Xu et al. (2018) developed an integrated numerical model (AHC) for simulating the soil water and solute dynamics, heat transport, and crop growth and yield for Northwest China. Despite the previous efforts of investigating the effect of agricultural managements on soil water and salt dynamics, and crop yields, few have investigated the influence of soil layer on retaining water while alleviating salinization for ensuring stable crop yields in arid region with shallow groundwater table and high evaporative demand. Besides, the influence of salt on soil evaporation is ignored in the agroecosystem process simulations. Typically, the Richards equation-based models usually adopt the arithmetic averaging method to calculate the internodal conductivities for solving the Richards equation (Simunek et al. 2005), but few studies had used geometric mean with more accuracy and stability of calculated water flux into the cropland with salinization. For layered soil, only a limited number of studies had discussed the effect of different averaging methods on water flow under soil column condition (Brunone et al. 2003; Szymkiewicz and Helmig 2011).

The objectives of this study were (a) to calibrate and validate the agro-eco-hydrological model LAWSTAC with data on soil water and salt, as well as sunflower growth in Arid Northwest China with a shallow groundwater table, and (b) to evaluate the effects of soil capping consisting of a fine soil overlying a coarse soil on simulated water storage and salt accumulation in root zone and corresponding crop yield. Results aimed to provide an improved knowledge on practices for saline soil reclamation and agricultural production in the salinized/barren land of the arid area.

\section{Materials and methods}

\subsection{Field experiment}

\subsubsection{The study area}

The experiment was conducted at the Jiefangzha Irrigation Scheme (JFIS; $40^{\circ} 48^{\prime} \mathrm{N}, 107^{\circ} 05^{\prime} \mathrm{E}$ ) of the Hetao Irrigation District (HID), Inner Mongolia Autonomous Region of China. The study area, JFIS, is the second largest irrigation scheme in the HID. The site has a typical arid and semiarid continental climate. The annual average temperature is $8.2^{\circ} \mathrm{C}$ with sunshine hours per year ranging from 3100 to 3300 . The soil freezing period lasts for 180 days from November to late May. Mean annual precipitation and pan evaporation are 160 and $2240 \mathrm{~mm}$, respectively. The depth to groundwater table 
varies from 0.5 to $3.0 \mathrm{~m}$. Soils in the HID are mainly formed from alluvial deposits and have silt loam to sandy loam textures (US soil taxonomy). Soil types are classified as fluvoaquic soils, meadow soils, bog soils, solonetz, and eolian sandy soils, according to the Genetic Soil Classification of China (Shi et al. 2004).

The agricultural fields are irrigated using surface flood irrigation with water diverted from the Yellow River. The experimental area is flat with shallow groundwater table due to the seepage from canals and deep percolation from croplands. High evaporative demand has led to salt accumulation in the surface soil and root zone, and has caused severe secondary soil salinization (Xu et al. 2015). The common practice to alleviate salts in the root zone was to leach during fallow season. However, due to the decreasing allocation of water resources for agricultural production in the arid area, leaching with large amounts of irrigation water is no longer viable and new strategies need to be explored.

\subsubsection{Experimental design}

Field experiment was conducted in Yangchang canal command area of JFIS during 2012 and 2013 (Ren et al. 2016). The sunflower was cultivated in a 0.4-ha experimental plot. The sowing and harvesting dates were 31 May and 20 September in 2012, and 3 June and 21 September in 2013, respectively. Surface flood irrigation was applied to the field two to three times during the season and a trapezoidal thinwall weir was used to measure the volume (Table 1). Before sowing, about $200 \mathrm{~mm}$ of irrigation was applied to the sunflower field to leach salts below the root zone. The total dissolved solid concentration of the irrigation water was $0.5 \mathrm{~g} \mathrm{~L}^{-1}$. Meteorological data collected from the nearby Linhe weather station $\left(41^{\circ} 46^{\prime} \mathrm{N}, 107^{\circ} 24^{\prime} \mathrm{E}\right)$ include sunshine hours, maximum and minimum air temperature, precipitation, wind speed, and relative humidity.

To characterize the soil physical properties, soil samples were collected from the surface to the depth of $3.0 \mathrm{~m}$. Using undisturbed soil samples of $100 \mathrm{~cm}^{3}$, the saturated hydraulic conductivity was determined using constant-head permeameter (Wit 1967), and the saturated soil water content and the dry bulk density were obtained by oven drying method (Grossman and Reinsch 2002). The disturbed soil samples were used to determine the percentages of sand, silt, and clay using laser particle size analyzer (Malvern MS2000, UK). The soil profile was classified into four horizons according to the soil physical properties (Table 2). Although soil textures in the profile was silt loam (US soil taxonomy), the soil particle size distributions, bulk densities (Table 2), and the corresponding hydraulic characteristics (Table 3) changed with soil depth. Soil samples were also collected every 7 to 15 -day interval to monitor soil water and salt contents from the sampling depths of $0-10,10-20,20-40,40-60,60-80$, and 80 $100 \mathrm{~cm}$. Soil salt content $\left(\mathrm{SSC}, \mathrm{g} \mathrm{kg}^{-1}\right.$ ) was first empirically obtained from the electrical conductivity of the 1:5 soil water extract, and then, the salt concentration $\left(C_{s w} \mathrm{~g} \mathrm{~L}^{-1}\right)$ was calculated by using soil water content $\left(\theta, \mathrm{cm}^{3} \mathrm{~cm}^{-3}\right), \mathrm{SSC}$, and bulk density $\left(\rho, \mathrm{g} \mathrm{cm}^{-3} ; \mathrm{kg} \mathrm{L}^{-1}\right.$ ), i.e., $C_{s w}=\mathrm{SSC} \cdot \rho / \theta$ (Xu et al. 2013). The groundwater levels in the different observation wells were measured by a water level logger (HOBO-U20, USA), and the average groundwater depth were 1.3 and $1.4 \mathrm{~m}$ for 2012 and 2013 crop seasons, respectively. The groundwater electrical conductivity $\left(E C_{w}, \mathrm{mS} \mathrm{cm}^{-1}\right)$ was measured every 10 days and converted to salt concentration $\left(C_{w}\right.$, $\mathrm{g} \mathrm{L}^{-1}$ ) using the empirical relationship $C_{w}=0.69 E C_{w}$ (Ren et al. 2016).

Meanwhile, the crop height data were collected every 10 15 days using a tape, and leaf area index (LAI) was measured every 15 days using ACCUPAR-LP80 (Decagon Devices, USA). When sunflower was ripe, 3 representative sampling locations were determined in the experimental field and 10 plants were continuously selected at each location in the direction of the crop row. The selected plants at each sampling location were harvested together manually. After drying the water content of seeds to $5 \%$, seed yield per plant was obtained by averaging the 10 plant yields for each sampling location. In total, 3 replicates of seed yield per plant were calculated. Based on the planting density of sunflower, the seed yields per plant were converted to seed yields per hectare. The mean value and standard deviation of the seed yield were calculated based on the 3 replicates.

\subsection{Model description}

A one-dimensional (1D) agro-eco-hydrological model LAWSTAC (Fig. 1) is used in this study (Chen et al. 2019). LAWSTAC model integrates processes such as evapotranspiration, water flow, solute transport, root water uptake, and

Table 1 Irrigation schedule of sunflower in 2012 and 2013

\begin{tabular}{llllll}
\hline Year & Date & Irrigation depth $(\mathrm{mm})$ & Year & Date & Irrigation depth (mm) \\
\hline 2012 & June 22 & 90 & 2013 & June 27 & 103 \\
& August 2 & 92 & & July 17 & 106 \\
& & & August 8 & 90 \\
\hline
\end{tabular}


Table 2 Soil physical properties at the experimental site

\begin{tabular}{llllll}
\hline $\begin{array}{l}\text { Depth } \\
(\mathrm{cm})\end{array}$ & \multicolumn{2}{l}{ Textural fractions $(\%)$} & $\begin{array}{l}\text { Soil } \\
\text { texture }\end{array}$ & $\begin{array}{l}\text { Bulk density } \\
\left(\mathrm{g} \mathrm{cm}^{-3}\right)\end{array}$ \\
\cline { 2 - 4 } & $\begin{array}{l}\text { Sand }(2.0- \\
0.05 \mathrm{~mm})\end{array}$ & $\begin{array}{l}\text { Silt }(0.05- \\
0.002 \mathrm{~mm})\end{array}$ & $\begin{array}{l}\text { Clay } \\
(<0.002 \mathrm{~mm})\end{array}$ & \\
\hline $0-40$ & 25.7 & 63.8 & 10.5 & Silt loam & 1.51 \\
$40-170$ & 32.4 & 61.2 & 6.4 & Silt loam & 1.44 \\
$170-250$ & 2.1 & 72.6 & 25.3 & Silt loam & 1.51 \\
$250-300$ & 20.1 & 67.5 & 12.4 & Silt loam & 1.44 \\
\hline
\end{tabular}

crop growth. In this model, the potential crop evapotranspiration is calculated using Penman-Monteith method (Allen et al. 1998) and partitioned into potential soil evaporation and potential crop transpiration based on LAI. The soil water flow in vertical direction is described by the Richards equation with root water uptake as a sink term. The van Genuchten-Mualem model (VG-M) (Mualem 1976; van Genuchten 1980) described the soil hydraulic properties. For simulating solute transport, the 1D convective-dispersive equation was applied. Because selective uptake may occur for ions in the root zone, the solute uptake was regarded as a source/sink term. Since salt uptake rate was relatively small (Munns et al. 2006), the salt uptake by plant was not considered. For the root water uptake, Feddes et al. (1978) function calculated the water stress factor with value range from 0 to 1 (no stress), and Maas and Hoffman (1977) described the salinity stress factor. The evaporation rate was controlled by surface soil water content and salt concentration. The crop growth was based on the EPIC crop growth model (Williams et al. 1989), which considers leaf area and root development, interception of solar radiation by the crop canopy, conversion of energy to biomass, and calculation of yield from biomass together with the effects of water, solute, and temperature stress. Biomass is computed from the photosynthetic active radiation intercepted by the crop leaf area using the plant radiation use efficiency. Belowground biomass (root weight) was partitioned from total biomass with fraction decreasing linearly from emergence to maturity. The LAI is divided into a growth stage and a senescence stage and computed as a function of heat units and crop stress. The crop height and root depth were estimated as functions of their maximum values and heat units. The vertical root distribution along its depth is treated as a linear function of the root depth (Shang et al. 2009). Crop yield is estimated from the aboveground biomass by using the harvest index, and the aboveground biomass is equal to total biomass minus root weight.

Implicit finite difference method was used for solving the Richards and convective-dispersive equations. For simulation with layered soil, 8 different averaging methods for estimating hydraulic conductivity in the middle of two adjacent nodes were considered in the model. In this study, geometric mean method was selected to calculate the hydraulic conductivity on the half nodes.

\subsection{Calibration and validation methods}

The simulation area from ground surface to the depth of $300 \mathrm{~cm}$ was composed of 4 layers (Table 2). For numerical simulation, the 4 layers were further discretized into 301 nodes with uniform spacing of $1 \mathrm{~cm}$.

The initial values of soil water content and salt concentration along the simulation domain were determined at the beginning of the sunflower growth seasons. For the soil water simulation, an atmospheric boundary condition was used as the upper boundary, which was governed by irrigation, precipitation, and evaporation. Due to the high groundwater
Table 3 Calibrated soil hydraulic and salt transport parameters

\begin{tabular}{|c|c|c|c|c|c|c|c|c|}
\hline Depth $(\mathrm{cm})$ & $\begin{array}{l}\theta_{r} \\
\left(\mathrm{~cm}^{3} \mathrm{~cm}^{-3}\right)\end{array}$ & $\begin{array}{l}\theta_{s} \\
\left(\mathrm{~cm}^{3} \mathrm{~cm}^{-3}\right)\end{array}$ & $\begin{array}{l}\alpha \\
\left(\mathrm{cm}^{-1}\right)\end{array}$ & $\begin{array}{l}n \\
(-)\end{array}$ & $\begin{array}{l}K_{s} \\
\left(\mathrm{~cm} \mathrm{day}{ }^{-1}\right)\end{array}$ & $\begin{array}{l}l \\
(-)\end{array}$ & $\begin{array}{l}D_{L} \\
(\mathrm{~cm})\end{array}$ & $\begin{array}{l}D_{0} \\
\left(\mathrm{~cm}^{2} \text { day }^{-1}\right)\end{array}$ \\
\hline 0-40 (SL1) & 0.05 & 0.42 & 0.010 & 1.5 & 13.0 & 0.5 & 20 & 10 \\
\hline $\begin{array}{r}40-170 \\
\text { (SL2) }\end{array}$ & 0.04 & 0.47 & 0.012 & 1.5 & 18.4 & 0.5 & 20 & \\
\hline $\begin{array}{r}170-250 \\
\text { (SL3) }\end{array}$ & 0.08 & 0.51 & 0.007 & 1.2 & 4.8 & 0.5 & 20 & \\
\hline $\begin{array}{r}250-300 \\
\text { (SL4) }\end{array}$ & 0.06 & 0.44 & 0.012 & 1.7 & 22.2 & 0.5 & 20 & \\
\hline
\end{tabular}

SL is a shortened form of silty loam, $\theta_{r}$ and $\theta_{s}$ are the residual and saturated soil water content respectively, $\alpha$ is the air-entry parameter, $n$ is the pore size distribution parameter, $l$ is the pore connectivity parameter, $K_{s}$ is the saturated hydraulic conductivity, $D_{L}$ is the longitudinal dispersivity, and $D_{0}$ is the molecular diffusion coefficient in free water 
Fig. 1 The framework of the LAWSTAC model. $\mathrm{ET}_{p}$ is the potential evapotranspiration $\left(\mathrm{cm} \mathrm{day}{ }^{-1}\right) ; E_{p}$ and $T_{p}$ are, respectively, the potential soil evaporation and crop transpiration $\left(\mathrm{cm} \mathrm{day}^{-1}\right) ; E_{a}$ and $T_{a}$ are the actual soil evaporation and crop transpiration $\left(\mathrm{cm} \mathrm{day}^{-1}\right)$, respectively; $f_{1}$ and $f_{2}$ are the water and salinity stress response functions for calculating $E_{a}$ and $T_{a}$, respectively; $\theta$ is the surface soil water content $\left(\mathrm{cm}^{3} \mathrm{~cm}^{-3}\right) ; c$ is the surface salt concentration $\left(\mathrm{g} \mathrm{L}^{-1}\right) ; K_{c}$ is the crop coefficient under optimal environmental conditions; $\mathrm{LAI}$ is the leaf area index; GW represents groundwater, and WS is the water stress

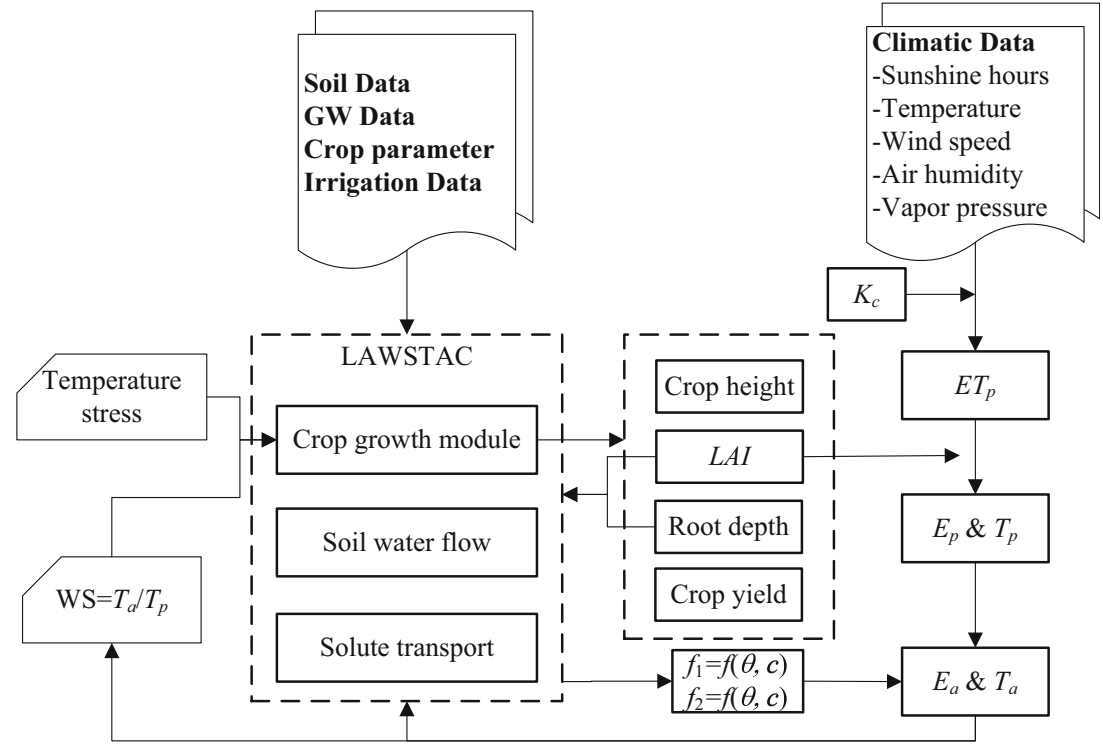

table, a variable pressure head boundary condition was specified at the bottom, which was determined by the observed groundwater level. For the solute transport, the upper boundary condition was defined as a flux type and the lower boundary as a concentration type.

The input parameters related with soil hydraulic property, solute transport, and crop growth were initially specified before simulation and adjusted based on the measured data in the calibration stage. The soil hydraulic characteristics $\theta_{r}, \theta_{s}, \alpha, n$, $l$, and $K_{s}$ in Table 3 were predicted by Rosetta pedotransfer functions (Schaap et al. 2001) using measured soil particle size fractions and bulk density (see Table 2). The values of solute transport parameters $\left(D_{L}\right.$ and $D_{0}$ listed in Table 3$)$ and root water uptake parameters $\left(h_{0}, h_{1}, h_{2 h}, h_{2 l}\right.$, and $h_{3}$ listed in Table 4) were obtained from Wesseling et al. (1991). The initial sunflower growth parameters (see Table 4) were from Williams et al. (1989), and initial evaporation stress parameters $\left(\theta_{1}, \theta_{2}\right.$, and $k_{p}$ listed in Table 4$)$ were determined according to Chen et al. (2019).

The measured data of soil moisture, salt content, and sunflower physiological index/yield during growth seasons were used to calibrate and validate the LAWSTAC model. Because there were more measurements in 2013 than 2012, the LAWSTAC was calibrated using experimental data of 2013, and was validated with the 2012 data. During calibration, a trial-and-error method was used to obtain a good agreement between the simulated and the observed data. In addition, the model performance was evaluated by statistical indicators (Moriasi et al. 2007), including the root mean square error (RMSE), the index of agreement $(d)$, the Nash and Sutcliffe model efficiency (NSE), the coefficient of determination $\left(R^{2}\right)$, and the percent bias (PBIAS) as shown in Eqs. (1-5).

$$
\begin{aligned}
& R M S E=\sqrt{\frac{1}{n} \sum_{k=1}^{n}\left(P_{k}-O_{k}\right)^{2}} \\
& d=1-\frac{\sum_{k=1}^{n}\left(P_{k}-O_{k}\right)^{2}}{\sum_{k=1}^{n}\left(\left|P_{k}-\bar{P}\right|+\left|O_{k}-\bar{O}\right|\right)^{2}} \\
& N S E=1-\frac{\sum_{k=1}^{n}\left(P_{k}-O_{k}\right)^{2}}{\sum_{k=1}^{n}\left(O_{k}-\bar{O}\right)^{2}} \\
& R^{2}=\left[\frac{\sqrt{\sum_{k=1}^{n}\left(O_{k}-\bar{O}\right)\left(P_{k}-\bar{P}\right)}}{\left.P B I A S=\frac{\sum_{k=1}^{n}\left(O_{k}-\bar{O}\right)^{2} \sum_{k=1}^{n}\left(P_{k}-\bar{P}\right)^{2}}{\sum_{k=1}^{n} O_{k}}\right]^{2}}\right]^{2} \\
& P
\end{aligned}
$$

where $P_{k}$ and $O_{k}(k=1,2, \ldots \ldots, n)$ are, respectively, the simulated and observed values, $\bar{P}$ and $\bar{O}$ are, respectively, the average simulated and observed values, and $n$ is the number of observations. The value of RMSE and PBIAS approach 0.0, and $d$, NSE, and $R^{2}$ values are close to 1.0 for a good model performance.

To understand the influence of model parameter uncertainties on the simulation results, uncertainty analysis was conducted for the calibrated model. For a physically based agro-hydrological model based on the Richards equation for 
Table 4 Calibrated values of crop and soil parameters in crop growth model, root water uptake model, and evaporation stress model

\begin{tabular}{|c|c|}
\hline Parameters & Values \\
\hline Base temperature for crop growth, $T_{b}\left({ }^{\circ} \mathrm{C}\right)$ & 6.0 \\
\hline Optimal temperature for crop growth, $T_{0}\left({ }^{\circ} \mathrm{C}\right)$ & 24.0 \\
\hline Maximum crop height, $H_{\max }(\mathrm{cm})$ & 177.0 \\
\hline Maximum root depth, $\mathrm{RD}_{\max }(\mathrm{cm})$ & 90.0 \\
\hline Maximum potential leaf area index, $\mathrm{LAI}_{\max }\left(\mathrm{m}^{2} \mathrm{~m}^{-2}\right)$ & 5.0 \\
\hline Maximum leaf area index under crop stress factor, $\mathrm{LAI}_{0}\left(\mathrm{~m}^{2} \mathrm{~m}^{-2}\right)$ & 4.6 \\
\hline Leaf area index decline rate, $L_{r}(-)$ & 0.6 \\
\hline Parameter for converting energy to biomass, $\mathrm{BE}\left(\mathrm{kg} \mathrm{m}^{2} \mathrm{ha}^{-1} \mathrm{MJ}^{-1}\right)$ & 40.0 \\
\hline Point in the growth season when leaf area begins to decline, $\mathrm{HUI}_{0}(-)$ & 0.56 \\
\hline Extinction coefficient, $\beta(-)$ & 0.55 \\
\hline Harvest index, HI (-) & 0.25 \\
\hline Total potential heat units required for crop maturation, $\mathrm{PHU}\left({ }^{\circ} \mathrm{C}\right)$ & 2000.0 \\
\hline Ratio of root water uptake in the upper half of root zone to the total water uptake, $m_{r}(-)$ & 0.70 \\
\hline$h$ below which roots start to extract water, $h_{0}(\mathrm{~cm})$ & -0.1 \\
\hline$h$ below which optimal roots uptake water starts, $h_{1}(\mathrm{~cm})$ & -5 \\
\hline$h$ below which water uptake water reduction starts at high atmospheric demand, $h_{2 h}(\mathrm{~cm})$ & -300 \\
\hline$h$ below which water uptake water reduction starts at low atmospheric demand, $h_{2 l}(\mathrm{~cm})$ & -400 \\
\hline$h$ below which water uptake is zero, $h_{3}(\mathrm{~cm})$ & $-10,000$ \\
\hline Salinity threshold below which no salt stress, $\mathrm{EC}_{\max }\left(\mathrm{dS} \mathrm{m}^{-1}\right)$ & 4.0 \\
\hline Decline rate of root water uptake, $\mathrm{EC}_{\text {slop }}\left(\% \mathrm{~m} \mathrm{dS}^{-1}\right)$ & 6.4 \\
\hline Threshold value below which the actual evaporation rate becomes $0, \theta_{1}\left(\mathrm{~cm}^{3} \mathrm{~cm}^{-3}\right)$ & 0.07 \\
\hline $\begin{array}{l}\text { Threshold value above which the actual evaporation rate becomes potential value, } \theta_{2} \\
\left(\mathrm{~cm}^{3} \mathrm{~cm}^{-3}\right)\end{array}$ & 0.26 \\
\hline Parameter for salt stress on evaporation, $k_{p}(-)$ & 0.0001 \\
\hline
\end{tabular}

$h$ is the pressure head

water flow, advective-dispersive equation for solute transport, and EPIC crop growth module, Xu et al. (2016) used a global method for parameter sensitivity analysis and found that the highly sensitive parameters included soil hydraulic parameters $\left(\theta_{s}, \alpha, n\right.$, and $\left.K_{s}\right)$, salt transport and salt stress parameters $\left(D_{L}\right.$, $\mathrm{EC}_{\max }$, and $\left.E C_{\text {slop }}\right)$, and crop growth parameters ( $T_{b}, \mathrm{LAI}_{\max }$, $L_{r}, \mathrm{HUI}_{0}$, and PHU). In the uncertainty analysis, the calibrated values of the highly sensitive parameters were treated as reference values, and the variation range of these parameters were set $\pm 10 \sim 50 \%$ of the reference values (Table 5), assuming that the selected parameters followed uniform distribution. Random values of the 16 parameters are generated within the range, with each parameter to be sampled only once for one group, and totally 50 groups of parameters were generated to drive the model simulation for each crop season.

\subsection{Scenario analysis}

Previous research showed that a coarse sand layer underlying fine textured soils can reduce infiltration rate (Miller and Gardner 1962), and depress water and solute transport during evaporation for a deep groundwater table (Shi et al. 2005). In this research, we used a series of scenarios to investigate how soil capping with a fine layer overlying a coarse layer
Table 5 Variation range of the highly sensitive parameters in the

\begin{tabular}{ll}
\hline Parameter & Range \\
\hline$\theta_{s 1}$ & $0.378-0.462$ \\
$\theta_{s 2}$ & $0.423-0.517$ \\
$\alpha_{1}$ & $0.006-0.014$ \\
$\alpha_{2}$ & $0.007-0.017$ \\
$n_{1}$ & $1.2-1.8$ \\
$n_{2}$ & $1.2-1.8$ \\
$K_{s 1}$ & $6.5-19.5$ \\
$K_{s 2}$ & $9.2-27.6$ \\
$D_{L}$ & $10.0-30.0$ \\
$\mathrm{EC}_{\max }$ & $3.6-4.4$ \\
$\mathrm{EC}_{\text {slop }}$ & $5.76-7.4$ \\
$T_{b}$ & $5.4-6.6$ \\
$\mathrm{LAI}_{\max }$ & $4.0-6.0$ \\
$L_{r}$ & $0.48-0.72$ \\
$\mathrm{HUI}_{0}$ & $0.504-0.616$ \\
PHU & $1850.0-2150.0$ \\
\hline
\end{tabular}

Subscripts 1 and 2 represent the first and the second soil layer, respectively uncertainty analysis 
Table 6 Soil capping sequences and corresponding thicknesses in the scenarios B to F

\begin{tabular}{llllll}
\hline Profile & B & C & D & E & F \\
\hline $\begin{array}{l}\text { Sequence and } \\
\text { thickness }\end{array}$ & $\begin{array}{c}\text { SL1 }(20 \mathrm{~cm}) \text { overlying } \\
\text { sand }(0 \mathrm{~cm})\end{array}$ & $\begin{array}{c}\text { SL1 }(19 \mathrm{~cm}) \text { overlying } \\
\text { sand }(1 \mathrm{~cm})\end{array}$ & $\begin{array}{c}\text { SL1 }(17 \mathrm{~cm}) \text { overlying } \\
\text { sand }(3 \mathrm{~cm})\end{array}$ & $\begin{array}{c}\text { SL1 }(15 \mathrm{~cm}) \text { overlying } \\
\text { sand }(5 \mathrm{~cm})\end{array}$ & $\begin{array}{c}\text { SL1 }(10 \mathrm{~cm}) \text { overlying } \\
\text { sand }(10 \mathrm{~cm})\end{array}$ \\
\hline
\end{tabular}

influences water and salt movement as well as the crop yield (Fig. 2). The fine soil in the capping layer acted as a water reservoir, while the coarse layer as a capillary barrier. The fine soil material used in the capping layer was the native silt loam soil (SL1). The coarse soil material in the capping layer was a sand consisting of $87 \%$ of sand particles, $10 \%$ of silt particles, and $3 \%$ of clay particles, with the $\theta_{r}=0.04 \mathrm{~cm}^{3} \mathrm{~cm}^{-3}, \theta_{s}=$ $0.4 \mathrm{~cm}^{3} \mathrm{~cm}^{-3}, \alpha=0.04 \mathrm{~cm}^{-1}, n=2.06, K_{s}=150 \mathrm{~cm} \mathrm{day}^{-1}$, $D_{L}=20 \mathrm{~cm}$, and $D_{0}=10 \mathrm{~cm}^{2}$ day $^{-1}$ (Gao et al. 2017).

The designed thickness of the capping layer was $20 \mathrm{~cm}$ overlaying the ground surface. Therefore, the soil layer (20$320-\mathrm{cm}$ depth from the elevated ground surface) in the soil profile A (Fig. 2) denoted the existing soil without soil capping in the experimental site, and SL1, SL2, SL3, and SL4 were the original soil textures in the experiment site (Table 3 ). The scenario simulations included one control treatment (B in Fig. 2) and four treatments (C to F in Fig. 2) with different soil capping sequences. The detailed soil capping sequences in the scenarios B to F are listed in Table 6.

Various groundwater depth scenarios were designed for scenarios $\mathrm{C}$ and D, and simulated using the LAWSTAC. Scenario analysis was conducted to investigate the effect of possibly variation of groundwater depth on water and salt dynamic in the root zone, and crop yield under soil capping condition. The present groundwater depth for scenarios $\mathrm{C}$ and $\mathrm{D}$ was the reference value, written as $\mathrm{R}+0$. For scenarios of $\mathrm{R}$ $-10, \mathrm{R}-20, \mathrm{R}+10$, and $\mathrm{R}+20$, the reference groundwater depth would be 10 or $20 \mathrm{~cm}$ less, and 10 or $20 \mathrm{~cm}$ more from capping surface, respectively.

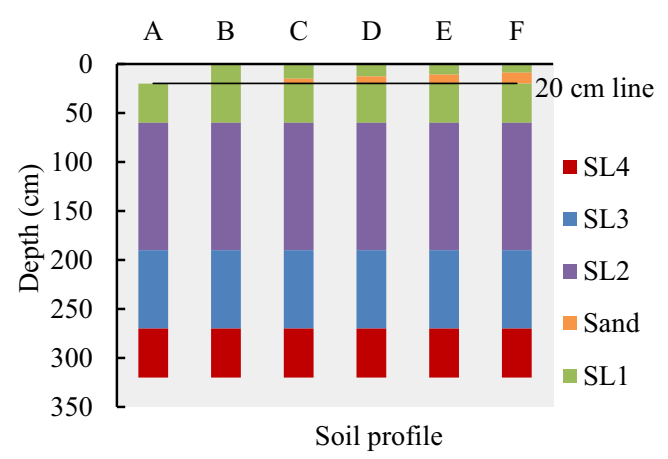

Fig. 2 Diagram of textural layers in original (A) and designed soil profiles (B to F). The depth is from the capping surface

\section{Results and discussion}

\subsection{Calibration process}

\subsubsection{Soil water content and salt concentration}

Simulated and observed soil water contents at different soil depths are presented in Fig. 3 (left). The LAWSTAC could capture both the trend and values of measured soil water content in the field with RMSE of $0.02 \mathrm{~cm}^{3} \mathrm{~cm}^{-3}, R^{2}$ of 0.86 , NSE of 0.79 , and PBIAS of $2.93 \%$. The fluctuations were more apparent at soil layers near the ground surface, while for deeper soil layers, only the fluctuations caused by three large irrigation events were visible. The average soil moisture at deeper soil layers was generally higher than the upper layers due to the capillary rise from shallow groundwater table.

The observed and simulated salt concentrations at different soil depths are shown in Fig. 3 (right). The fluctuations of salt concentrations were in the opposite direction than those of the soil water contents indicating dilution with irrigation. The comparison between observed and simulated salt concentration showed a RMSE = $0.74 \mathrm{~g} \mathrm{~L}^{-1}$, a $d=0.78$, a $\mathrm{NSE}=0.40$, and a PBIAS $=$ $2.49 \%$, which demonstrated a good prediction by the model. In addition, Fig. 3 shows that the model predicted uncertainty bands for soil moisture and salt concentration covered most of the observations, which indicated a reliable simulation of soil water and salt dynamics under the impacts of the parameter uncertainties.

\subsubsection{Crop height and seed yield}

The results of LAI and sunflower height showed a close match between the observed and simulated values (Fig. 4). The deviation of crop height in the late growth stage was due to crop bending caused by the increasing weight of sunflower heads. The values of RMSE, NSE, and $R^{2}$ were $0.28 \mathrm{~m}^{2} \mathrm{~m}^{-2}, 0.97$, and 0.98 for LAI, respectively. For the crop height, the NSE was 0.93 with an $R^{2}$ of 0.94 . In addition, most of measured LAI values located in the simulated uncertainty bands.

As shown in Table 7, the simulated crop yield was $4352 \mathrm{~kg} \mathrm{ha}^{-1}$ slightly greater than the observed yield. 
Fig. 3 Comparison of observed (o) and simulated (-) soil water content (left) and salt concentration (right) in different soil layers - results for calibration year 2013 along with precipitation $($ ) and irrigation $(\phi)$. Vertical bars correspond to the standard deviation of observations, and the gray band represents the simulation uncertainty
Fig. 4 Comparison of observed (o) and simulated (-) LAI (left) and crop height (right) as calibrated using 2013 measurements. The gray band represents the simulation uncertainty
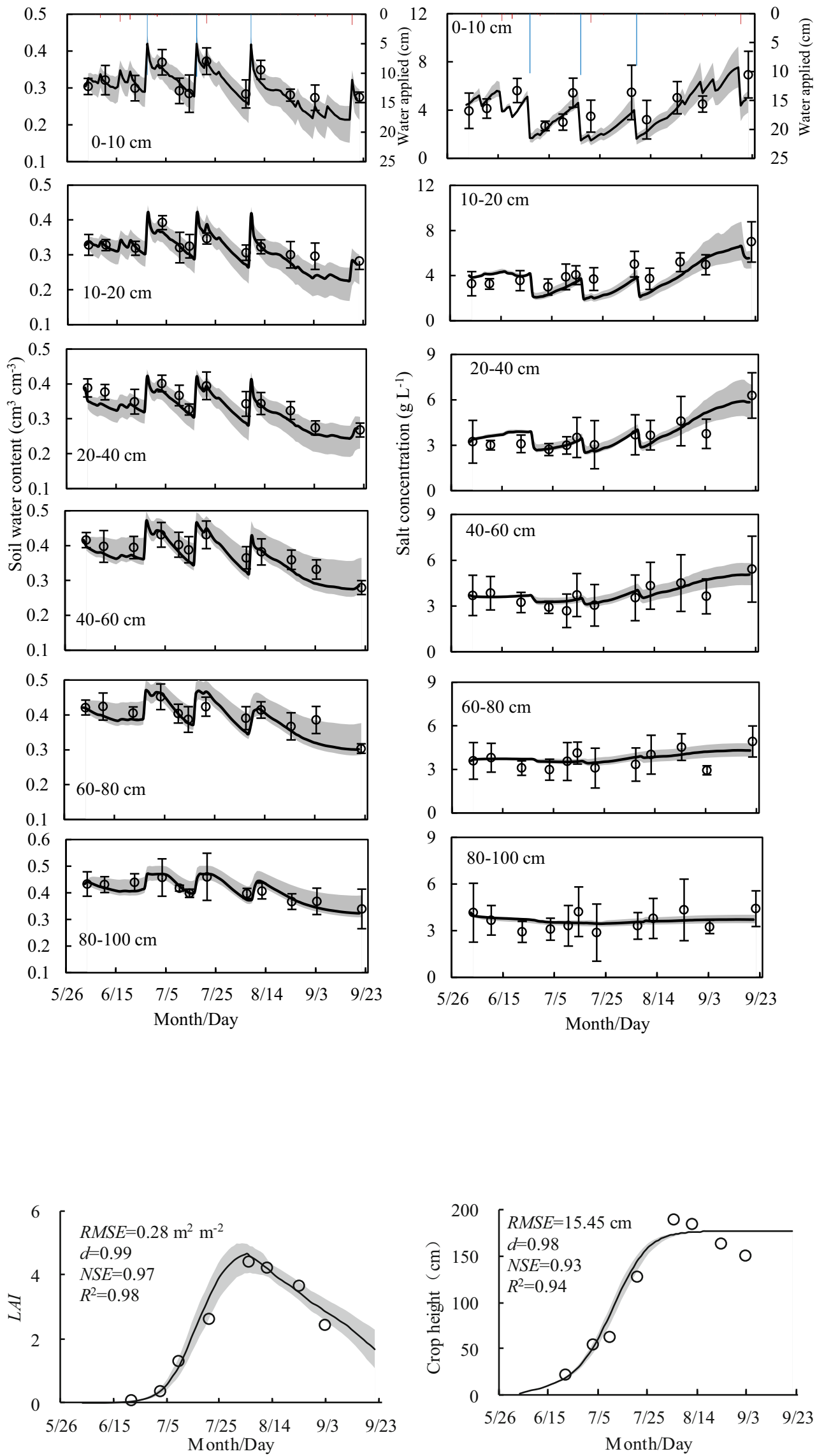
Table 7 Observed and simulated crop yields in 2012 and 2013

\begin{tabular}{lccc}
\hline Year & $\begin{array}{l}\text { Yield }\left(\mathrm{kg} \mathrm{ha}^{-1}\right) \\
\text { Measured }\end{array}$ & Simulated & Uncertainty \\
\hline 2012 & $4300 \pm 500$ & 4197 & $3452-4552$ \\
2013 & $4100 \pm 400$ & 4352 & $3577-4591$
\end{tabular}

The figures after the " \pm " sign correspond to the standard deviation

However, simulated yield was within a standard deviation of the observed and also within the range of simulated yield uncertainty. All these results confirmed the good performance of the LAWSTAC to simulate crop growth.

\subsection{Validation process}

\subsubsection{Soil water content and salt concentration}

As shown in Fig. 5, the simulated soil water content and salt concentration were in agreement with the measured values for various soil layers during validation with data of 2012 with the $d$ of 0.90 and $R^{2}$ of 0.72 for both soil water content and salt concentration. The RMSE, NSE, and PBIAS were $0.03 \mathrm{~cm}^{3} \mathrm{~cm}^{-3}, 0.53$, and $3.01 \%$ for soil water content, $0.66 \mathrm{~g} \mathrm{~L}^{-1}, 0.55$, and $-2.11 \%$ for salt concentration, respectively. Figure 5 also demonstrates that most of the measured soil water content and salt concentration were within the predicted uncertainty bands. The results confirmed that
Fig. 5 Comparison of observed (o) and simulated (-) soil water content (left) and salt concentration (right) in different soil layers for the validation year 2012 along with precipitation $(\phi$ ) and irrigation (). The gray band is the simulation uncertainty
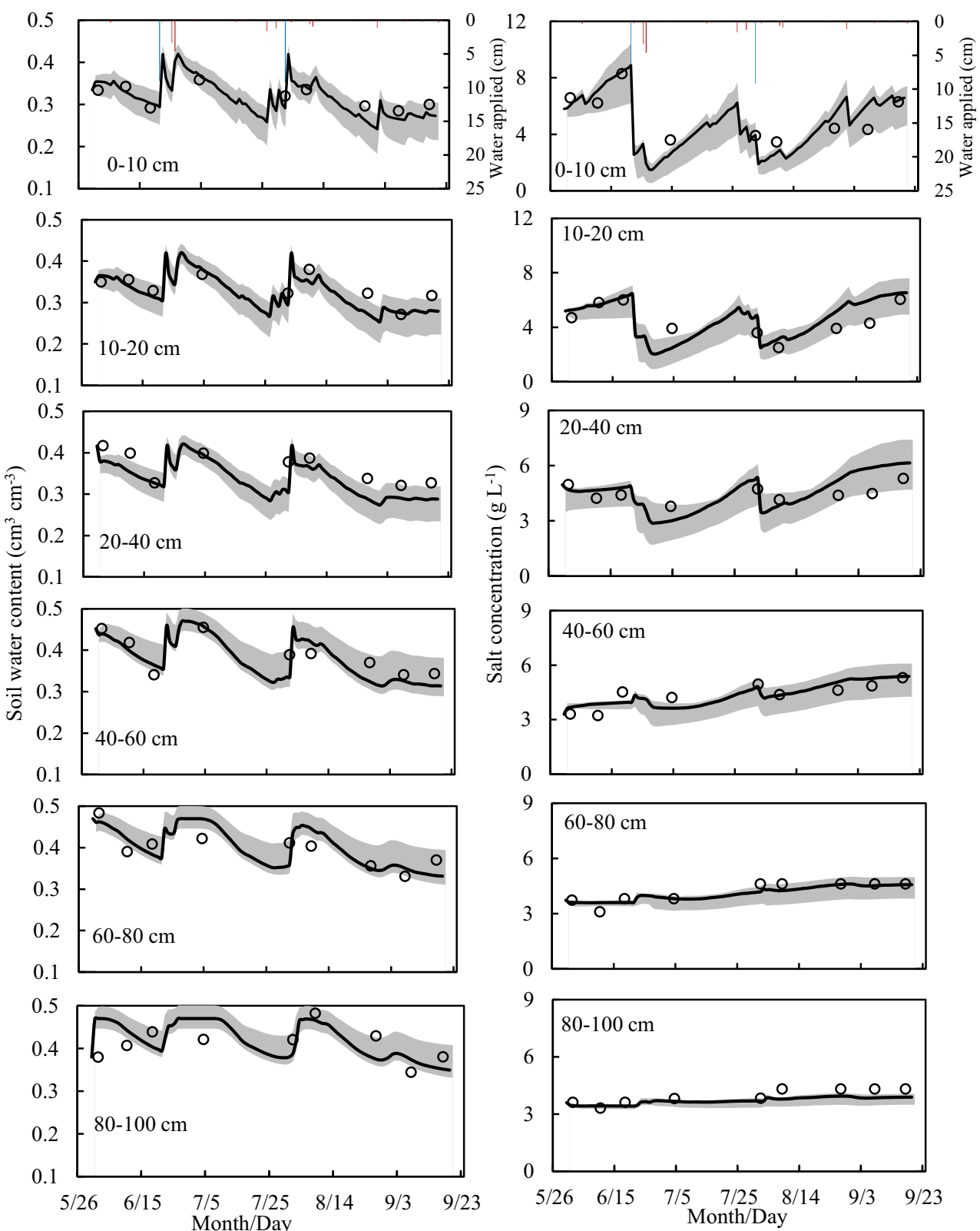
LAWSTAC was reliable to simulate water and salt dynamics in response to the parameter uncertainties under field condition.

\subsection{LAI, crop height, and seed yield}

The simulation results by LAWSTAC in validation showed good agreements with the measured data of $L A I$ and crop height (Fig. 6). The values of $d, N S E$ and $R^{2}$ (Fig. 6) for $L A I$ and the crop height also confirmed the model performances. As shown in Table 7, the simulated sunflower yield was less than the measured crop yield, but it was within a standard deviation of the observed results. In addition, the simulated uncertainty range for LAI and crop yield covered the measured data. The results indicated that LAWSTAC was reliable and could be used to simulate crop growth and seed yield.

\subsection{Water and salt balance in the root zone for the original soil profile}

The simulation results of soil water and salt components in the root zone during the crop growth seasons of 2012 and 2013 were analyzed for profile A. As shown in Table 8, actual evapotranspiration was above $400 \mathrm{~mm}$ with $T_{a}$ accounting for about $70 \%$ of $\mathrm{ET}_{a}$. The soil water content in the root zone in 2012 (averaged $0.35 \mathrm{~cm}^{3} \mathrm{~cm}^{-3}$ ) and 2013 (averaged $0.33 \mathrm{~cm}^{3} \mathrm{~cm}^{-3}$ ) crop seasons was all relatively high. Therefore, the higher root zone salt concentration in 2012 (averaged $4.48 \mathrm{~g} \mathrm{~L}^{-1}$ ) resulted in more stress on root water uptake than that in 2013 (averaged salt concentration $3.84 \mathrm{~g} \mathrm{~L}^{-1}$ ) (Fig. 7).

Deep percolation mainly occurred after large irrigation, with the cumulative depth of 140 and $117 \mathrm{~mm}$ in 2012 and 2013, respectively (Table 8). The simulated total amounts of salt leaching were 645 and $533 \mathrm{~g} \mathrm{~m}^{-2}$ for 2012 and 2013, respectively. Despite the large irrigation depth, water from capillary rise played an important role for crop growth since the time interval between irrigations was large and evapotranspiration demand was high. Accompanied with the capillary rise of soil water, the salt underneath was brought into the upper soil and accumulated in the soil surface and the root zone. The higher water table in 2012 , consequently higher capillary rise, resulted in greater salt accumulation (475 and $350 \mathrm{~g} \mathrm{~m}^{-2}$ for 2012 and 2013, respectively) in the root zone.

Salt storage in the root zone during the growth seasons slightly decreased in 2012 and 2013. Initial salt storage in the root zone was less in 2013 than 2012, mainly because of the leaching during fallow season between 2012 and 2013. It indicates that the negative balance of salt storage was largely due to the leaching during the fallow season for the original soil profile, which may not be sustainable due to the scarce agricultural water resources in arid areas.

\subsection{Soil water and salt distribution in the soil profile with a soil capping}

In order to understand the impact of an embedded sand layer in the soil capping on the soil water and salt distribution, we compared the simulated soil water storage and salt content for scenarios B to F in the soil above (0-10-cm depth) and below (20-90-cm depth) the sand layer during the crop season (Figs. 8 and 9). As shown in Fig. 8, the scenario with a thicker sand layer showed a slightly higher water storage in $0-10-\mathrm{cm}$ soil layer after each irrigation (e.g., scenario F), and then, it dropped rapidly, turning to have a much lower water storage before the next irrigation. It is because the upper fine soil could draw water from the lower sand layer due to the high suction of the fine soil, while the upward flow reduced when the sand layer lost too much water and turned into a capillary barrier with the rapid decrease of unsaturated hydraulic conductivity (Fig. 10) (Huang et al. 2013). With the thicker sand layer, the more prominent this phenomenon could be. As to the water storage in $20-90-\mathrm{cm}$ soil layer, with a thicker upper sand layer, the decrease of soil water storage was more mildly because it tended to keep more water (i.e., prevented the upward flow) in this layer. It is especially obvious at the late crop growth stage when the groundwater table was relatively deep. As to the water storage during the irrigation and rainfall event, less water was infiltrated into the $20-90-\mathrm{cm}$ soil with a sand layer above it (as shown in Fig. 8). It is mainly because the sand layer intercepted more water during infiltration process and thus spared less water for the lower layer.

As shown in Fig. 9, the salt content in 0-10-cm soil layer with a sand layer below was lower than that for scenario B
Fig. 6 Comparison of observed (o) and simulated (-) LAI (left) and crop height (right) during model validation year (2012). The gray band represents the simulation uncertainty
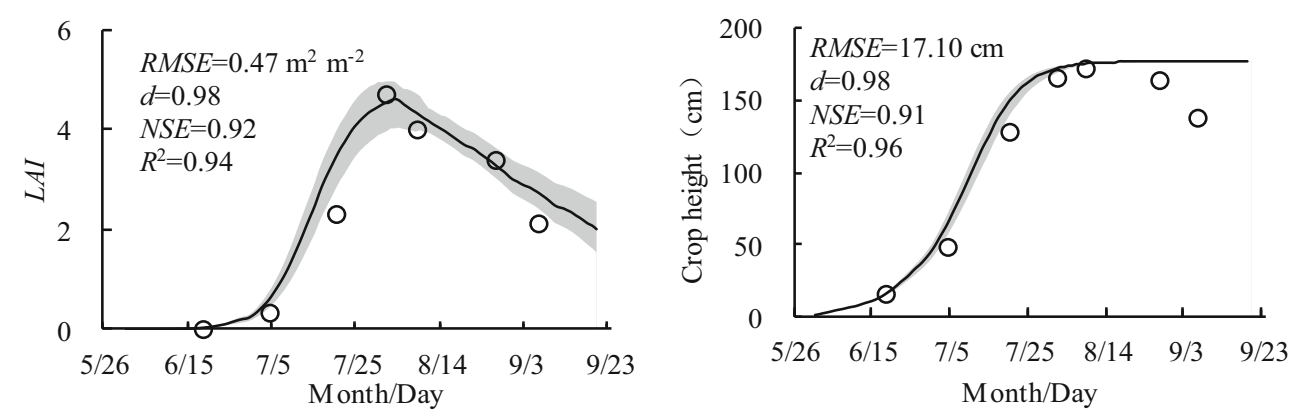
Table 8 Water and salt balance in the root zone for the original soil (A) during the simulation period from May 31 to September 20 in 2012 and from June 3 to September 21 in 2013

\begin{tabular}{llllll}
\hline & \multicolumn{2}{l}{2012} & & \multicolumn{2}{l}{2013} \\
\cline { 2 - 3 } \cline { 5 - 6 } & Water $(\mathrm{mm})$ & Salt $\left(\mathrm{g} \mathrm{m}^{-2}\right)$ & & Water $(\mathrm{mm})$ & Salt $\left(\mathrm{g} \mathrm{m}^{-2}\right)$ \\
\hline Season irrigation & 182 & 91 & 299 & 150 \\
Season rainfall & 161 & 0 & 87 & 0 \\
Initial storage & 374 & 1577 & & 351 & 1305 \\
Final storage & 276 & 1498 & & 257 & 1272 \\
Percolation & 140 & 645 & & 117 & 533 \\
Capillary rise & 126 & 475 & & 96 & 350 \\
Actual transpiration, $T_{a}$ & 295 & 0 & 323 & 0 \\
Actual evaporation, $E_{a}$ & 132 & 0 & & 136 & 0 \\
\hline
\end{tabular}

(without sand layer below) after an irrigation event, and the reduction was more obvious in scenarios with a thicker sand layer. This is because more salt in the upper soil was leached down with a sand layer below after a large amount of irrigation. In the soil water decreasing period, the sand layer acted as a capillary barrier (as mentioned above) and tended to take less salt upward into the $0-10-\mathrm{cm}$ soil layer. As to the salt content in the 20-90-cm soil layer, it was lower with sand layer above (scenarios $\mathrm{C}$ to $\mathrm{F}$ ) compared with that without the sand layer (scenario B) before the late crop growth stage, but inversely higher in the late crop growth stage. The reason is discussed below. Before the late crop growth stage, during the irrigation and rain, the salt in the $0-10-\mathrm{cm}$ soil was leached downward and parts of them were intercepted by the sand layer. Therefore, less salt migrated into the 20-90-cm soil with a thicker upper sand layer. The capillary rise into the crop root zone was also lower for scenarios C to F (85-104 mm and 64$82 \mathrm{~mm}$ in 2012 and 2013 crop season, respectively) than that for scenario B (106 $\mathrm{mm}$ in 2012 and $86 \mathrm{~mm}$ in 2013). Therefore, less salt from the deep soil was brought into the root zone through capillary rise for $\mathrm{C}$ to $\mathrm{F}$. As a result, the salt content in the 20-90-cm soil layer was lower for scenarios with an upper sand layer in this period. In the late crop growth stage without irrigation, the soil water content in the upper soil layer decreased greatly and a large amount of capillary rise occurred that brought more salt into the root zone. While at this stage the sand layer with low water content acted as a capillary barrier and inhibited the salt migration into the upper soil which left more salt in the 20-90-cm soil layer.

\subsection{Impacts of soil capping on water and salt storage in the root zone and crop yield}

By comparing the simulation results for scenarios $\mathrm{B}$ to $\mathrm{F}$ with the original soil profile $\mathrm{A}$, we investigated the effects of soil capping with increased sand layer thickness on the water storage and salt content in the root zone, and crop yield. Note that the groundwater depth increased for scenarios B to F compared with A, because of soil capping.

Figure 11a and $\mathrm{b}$ give the water storage (the average value of the whole growing season) in the root zone with and without soil capping in 2012 and 2013, respectively. Obviously soil capping reduced the soil water storage in the root zone. It is because soil capping increased the groundwater depth and reduced the capillary rise. As shown from the simulation, the capillary rise into the root
Fig. 7 Actual and potential transpiration $\left(T_{a}, T_{p}\right)$, actual and potential evaporation $\left(E_{a}, E_{p}\right)$, and vertical water flux $\left(Q_{\text {bot }}\right)$ at the bottom of the root zone along with rainfall (Rain), irrigation (Irrig), and groundwater depth (GWD) changes during sunflower's growth seasons of 2012 (a) and 2013 (b)
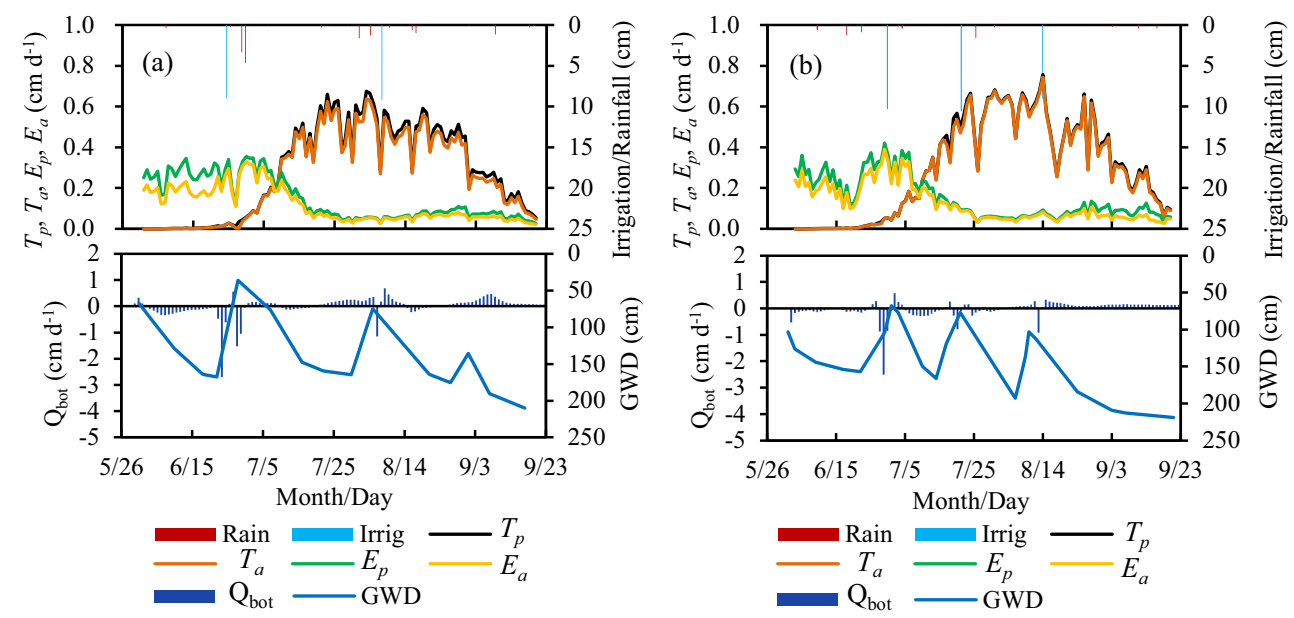
Fig. 8 Soil water storage in 0 $10 \mathrm{~cm}$ and $20-90-\mathrm{cm}$ soil layer based on simulation scenarios B to $\mathrm{F}$ with different thicknesses of sand layer in the soil capping for 2012 (left) and 2013 (right) seasons along with rainfall and irrigation

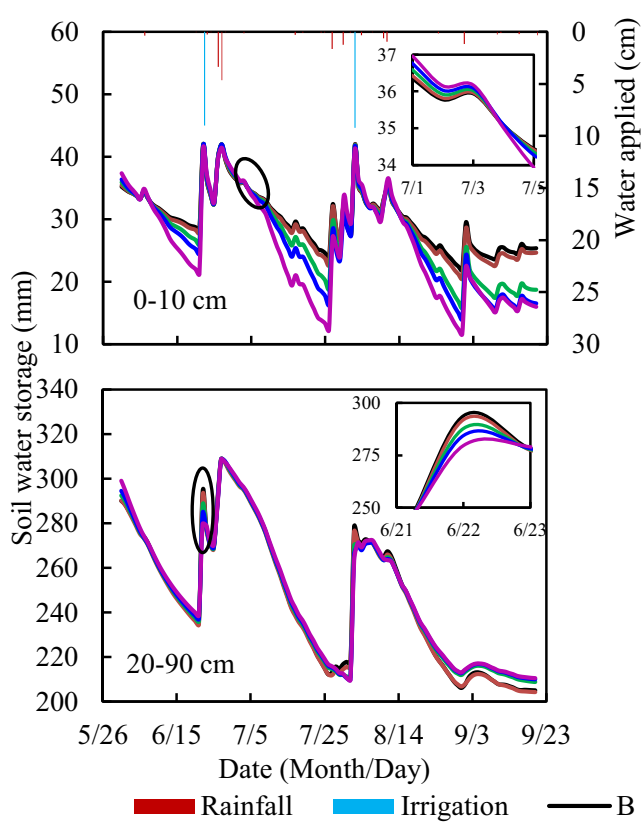

zone for scenarios $B$ to $F$ in 2012 season $(85-106 \mathrm{~mm})$ and 2013 season $(64-86 \mathrm{~mm})$ were all lower compared with treatment A (126 and $96 \mathrm{~mm}$ for 2012 and 2013, respectively), and the thicker sand layer in the soil capping induced less capillary rise into the root zone. Besides, the sand in the root zone usually showed a lower soil water content than the fine soil (Jury and Horton 2004). Though, as sand thickness increased in the soil capping, the average water storage in the root zone decreased compared with the treatment A without soil capping, the soil water stress to root water uptake changed little for scenarios B to D (averaged stress factor ranged
0.988-0.999 for the two crop seasons) compared with A (averaged stress factor was 0.998 for 2012 and 0.995 for 2013).

The average salt content (the average value of the whole growing season) in the root zone with and without soil capping are shown in Fig. 11c and d. Results show that the soil capping can reduce the average salt content in the root zone, and thicker sand layer showed better performance on preventing salt accumulation in the root zone. It is because the capillary rise into the root zone was less under soil capping with thicker sand layer condition, and the salt transported into the root zone through capillary rise was less. The less water
Fig. 9 Soil salt content in 0 $10 \mathrm{~cm}$ and $20-90-\mathrm{cm}$ soil layer based on simulation scenarios B to $\mathrm{F}$ with different thicknesses of sand layer in the soil capping for 2012 (left) and 2013 (right) seasons along with rainfall and irrigation
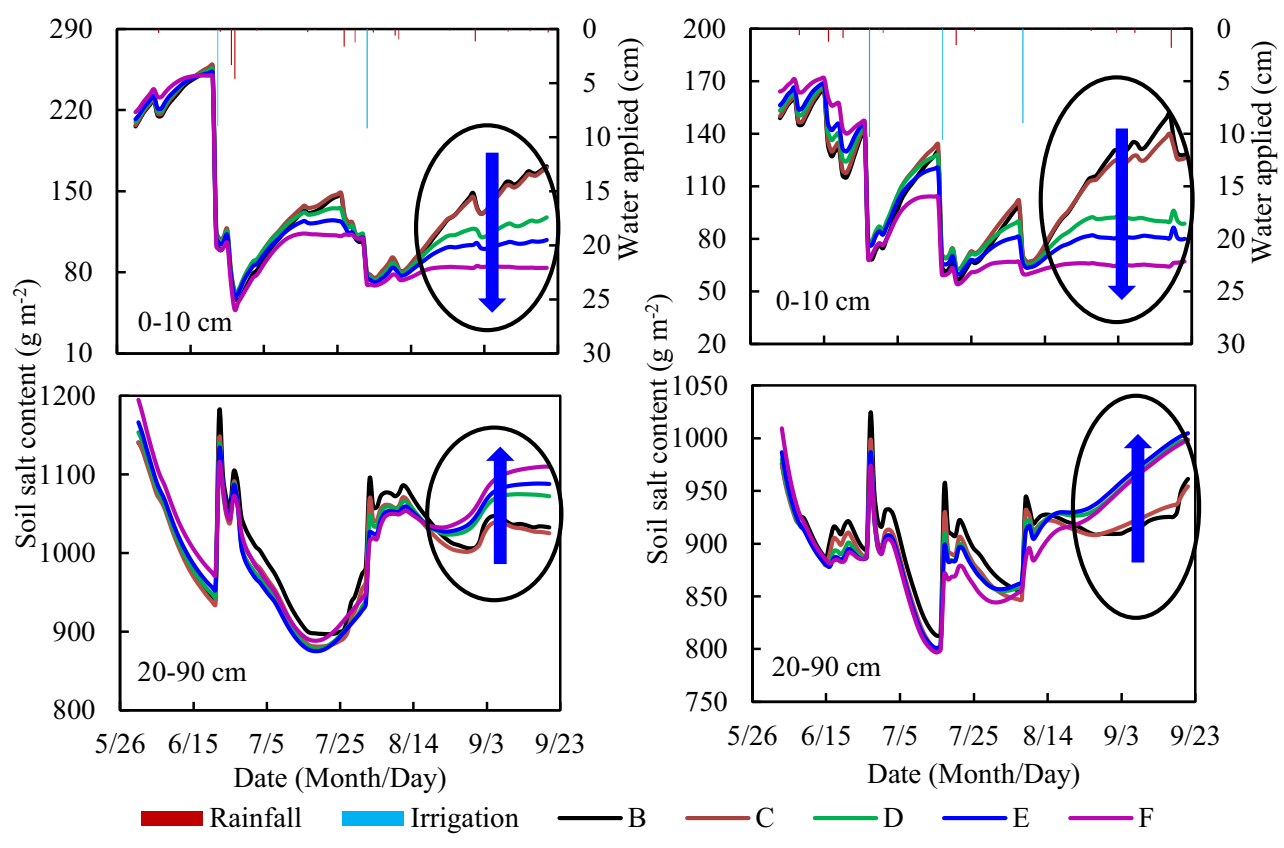
Fig. 10 Distribution of hydraulic conductivity in the root zone under soil capping with $(\mathrm{C})$ and without (B) sand layer conditions at the end of the 2012 (left) and 2013 (right) seasons

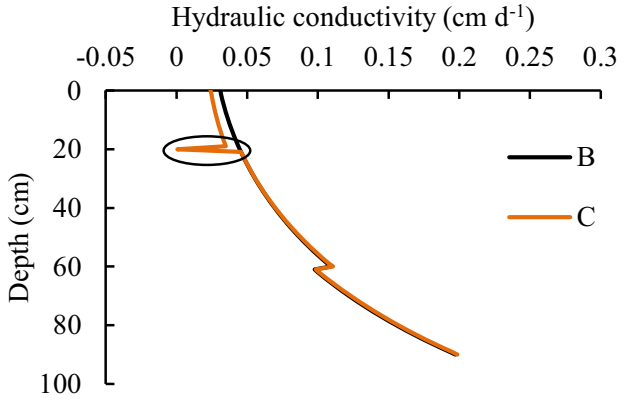

Hydraulic conductivity $\left(\mathrm{cm} \mathrm{d}^{-1}\right)$

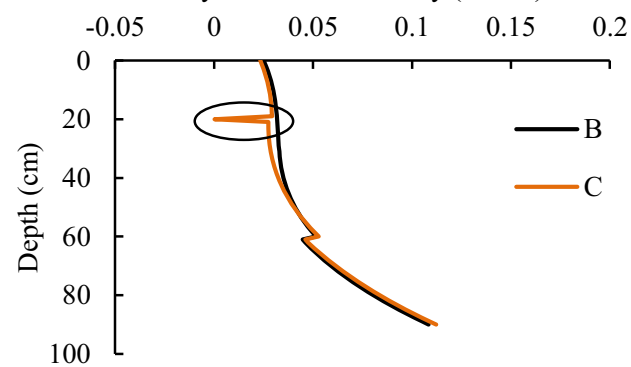

storage of the sand layer when there was no irrigation or rain also contributed to the less salt content in the root zone. As the sand thickness increased from 0 to $10 \mathrm{~cm}$, the average salt content in the root zone decreased by $7.8-14.9 \%$ for 2012 season and by $3.8 \%-11.9 \%$ for 2013 season, respectively, compared with the treatment A without soil capping, and the soil salt stress to root water uptake for scenarios B to F (averaged stress factor ranged $0.94-0.95$ for 2012 season and $0.97-$ 0.98 for 2013 season) was also reduced compared with A (averaged stress factor was 0.92 for 2012 and 0.97 for 2013).

As shown in Fig. 11e and $\mathrm{f}$, the percentage change of crop yield for scenarios B to $\mathrm{F}$ was $+1.9 \%,+2.0 \%,+2.2 \%,+$ $2.3 \%$ and $+0.4 \%$ for 2012 and $+0.6 \%$, $+0.8 \%,+0.3 \%$, -
$0.3 \%$, and $-2.5 \%$ for 2013 , compared with the yields without soil capping (A), respectively. It demonstrated that the crop yields generally increased with the soil capping than that without capping (except scenario E and F in 2013). The highest yield appeared in scenario $\mathrm{E}$ (soil capping with sand layer thickness $5 \mathrm{~cm}$ ) in 2012 and scenario C (soil capping with sand layer thickness $1 \mathrm{~cm}$ ) in 2013. The critical thickness of sand layer (i.e., the thickness with highest crop yield) varied in 2012 and 2013. It is because crop yield was affected by both the water availability and salt stress in the root zone, while the salt stress condition is different in these 2 years. In 2012, the salt content in the root zone was relatively high and tended to be the crucial restricting factor on crop yield compared with
Fig. 11 Average water storage (a, b) and salt content (c, d) in the root zone, and crop yield (e, f) along with the percentage changes () of scenarios B to F () compared with the original soil () in 2012 (a, c, e) and 2013 (b, d, f) seasons
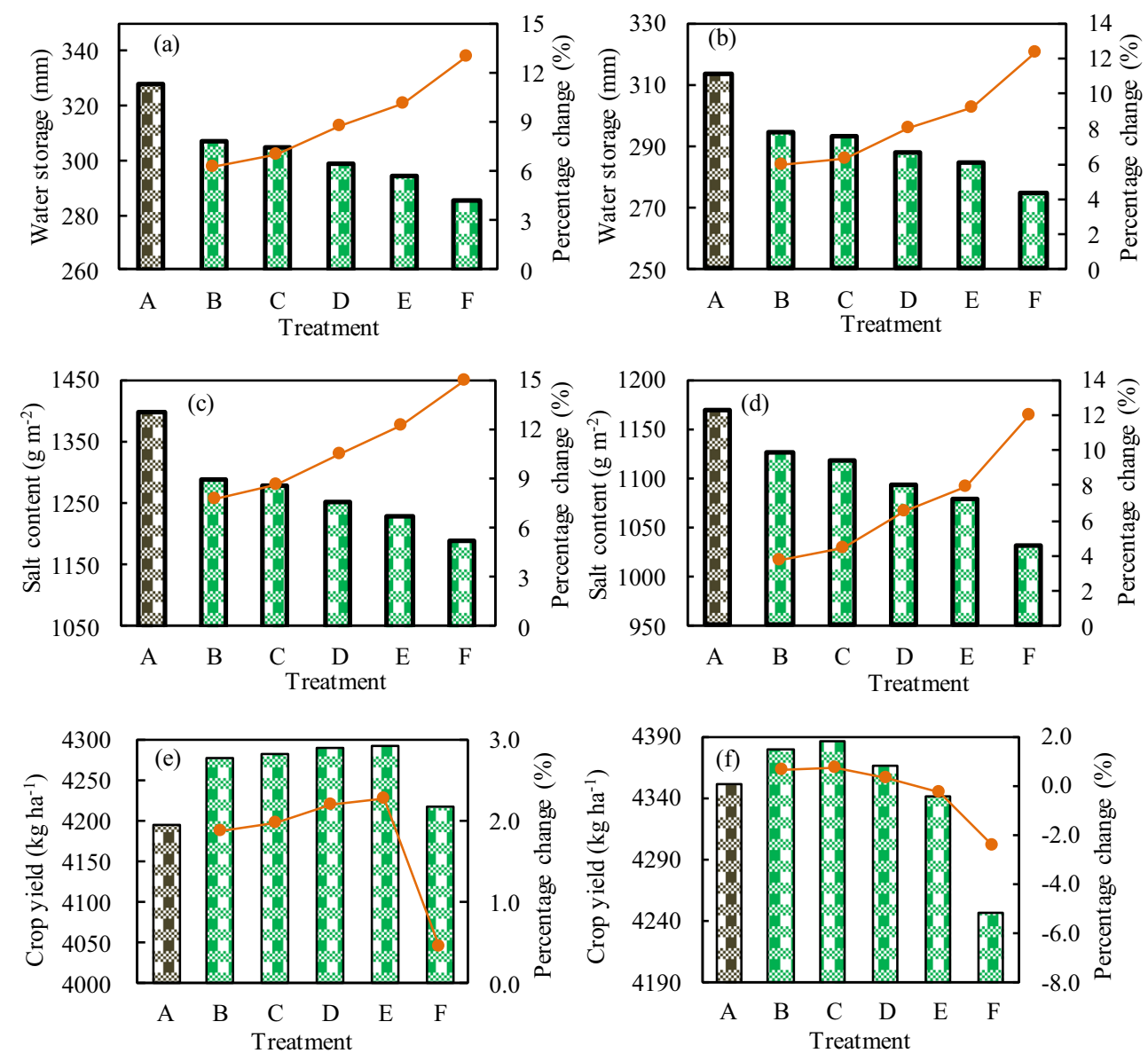
Fig. 12 Average water storage (a, b) and salt content (c, d) in the root zone, and crop yield (e, f) under various groundwater depth (GWD) conditions for scenarios $\mathrm{C}(\mathbf{a}, \mathbf{c}, \mathbf{e})$ and $\mathrm{D}(\mathbf{b}, \mathbf{d}, \mathbf{f})$ in 2012 and 2013 seasons
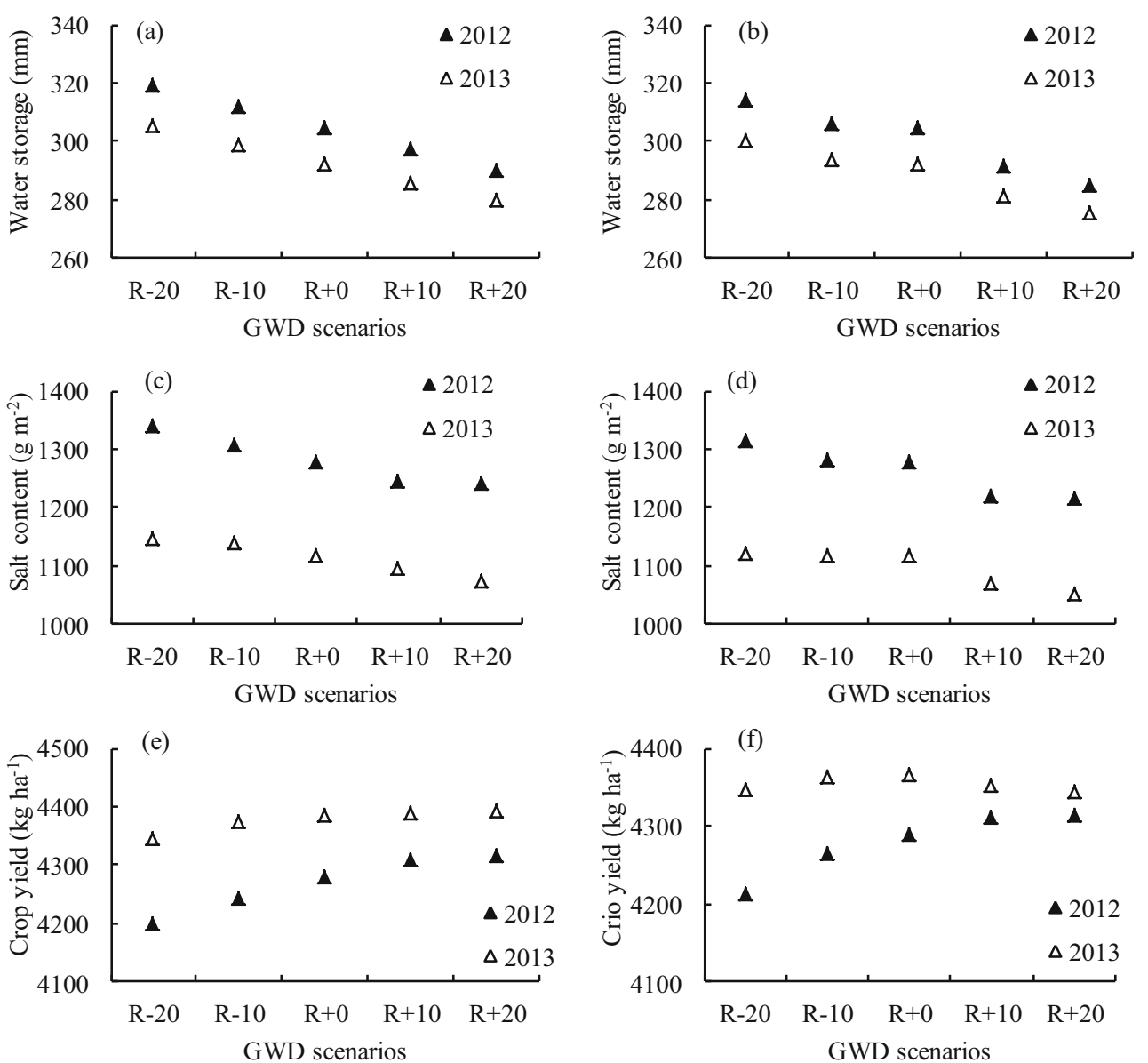

soil water availability (Fig. 11c and d). Therefore, although a thicker sand layer reduced the soil water storage in the root zone, it also effectively alleviated the salt accumulation in the root zone. As the sand thickness increased from $0 \mathrm{~cm}$ to the critical value (i.e., $5 \mathrm{~cm}$ ), the decreased osmotic stress outcompeted the increased water stress and resulted in an increase of actual transpiration (302-304 mm) and crop yield. However, if the sand thickness was larger than the critical value (i.e., scenario F), the negative effect of the water stress began playing the dominant role and resulted in the decrease of actual transpiration (296 mm) and crop yield. While in 2013, the salt stress was not so prominent compared with that in 2012 (Fig. 11c and d). Therefore the critical sand thickness was only $1 \mathrm{~cm}$ in 2013 . It also indicated that that the practice of soil capping with sand layer could work well in the soil with serious salinization problem.

Based on the above analysis, the soil capping with a thicker sand layer was more efficient for salt control in the root zone when salinization problem was serious. However, the sand layer could cause water stress to root uptake when its thickness was larger than a critical value. Therefore, the sand thickness in the soil capping should be within a range (e.g., 1-3 cm in HID) for increasing crop yield in saline regions with high groundwater tables.
This practice of soil capping could be a promising technique for the reclamation of salinized/barren land in the arid area with shallow groundwater tables.

\subsection{Groundwater depth on water and salt dynamics, and crop yield under soil capping}

The average water storage and salt content in the root zone from planting to harvest decreased as the groundwater depth became deeper (Fig. 12). It is because less capillary water moved upwards when the groundwater table was deeper, and the accumulation of salt in the root zone decreased under this condition. The crop yields increased with the increase of groundwater depth for scenario C both in 2012 and 2013 and for scenario D in 2012 (Fig. 12e and f), which indicated that the soil salt had a larger impact on crop growth. For scenario D in 2013, the crop yields increased then decreased with the groundwater depth. The increase was due to the reduced salt stress, and the decrease was a result of increased water stress for less water storage (Fig. 12). Compared with treatment $A$, the soil capping with sand layer of 1$3 \mathrm{~cm}$ thick (the thickness of above fine soil layer 19$17 \mathrm{~cm}$ correspondingly) was effective in salt alleviation 
and crop production when groundwater depth varies -10 $\sim+20 \mathrm{~cm}$ relative to the reference value. Therefore, this practice can be generalized to the similar saline area with groundwater table fluctuation within the range of the research results.

\section{Conclusions}

A coupled agro-eco-hydrological model, LAWSTAC, based on Richards equation, advection-dispersion equation, and crop growth mechanism, was applied to assess the soil water dynamics, soil salinity accumulation, and crop yield responses relative to different soil capping in an arid area with shallow saline groundwater. The model calibration and validation were conducted based on experimental data of 2013 and 2012, respectively. Simulation results of soil water content, salt concentration, leaf area index, crop height, and crop yield compared well with the experimental data. The assessment of soil capping with sand layer was carried out with the verified model based on the field experiment.

Simulation results indicated that for the whole root zone, the soil capping with a sand layer in the reconstructed soil could effectively reduce the salt content in the root zone, although it would also decrease the water storage compared with that in the original soil. For sand thickness of $1-3 \mathrm{~cm}$ in the soil capping, the decreased salt content in the root zone reduced salt stress to root water uptake, while the decreased water storage caused no obvious increase in water stress to root uptake, and thus, crop yield level was increased. In a long run, the soil capping of combinations of fine soil and coarse sand with certain thicknesses would be an alternative practice for saline soil reclamation and increasing crop yield in similar regions with high groundwater table and soil salinization problems.

Our study indicated that a sand layer in soil capping could reduce salt content in the root zone and create a low-salinity soil environment for the crop production, and meanwhile keep sufficient water storage, beneficial for crop production and cutting down the irrigation water for leaching the salt out of the crop root zone. This conclusion can provide guidance for optimizing the soil structure in greenhouse design or tackling heavy salinity soil reclamation in arid area with shallow groundwater tables. In a long run, such technique could be cost-effective compared with the benefit it produced.

Acknowledgments We sincerely thank Prof. Guanhua Huang and his research group in China Agricultural University for providing valuable experimental data to support this study. We also thank New Mexico State University Agricultural Experiment Station. Thanks to Mr. Frank Sholedice for editorial assistance.

Funding information This study was funded by the National Natural Science Foundation of China (grant numbers 51790535, 51379207) and the 111 plan from Ministry of Education and State Administration of Foreign Expert Affairs (grant number B14002).

\section{Compliance with ethical standards}

Conflict of interest The authors declare that they have no conflict of interest.

Ethical approval This article does not contain any studies with human participants or animals performed by any of the authors.

Open Access This article is licensed under a Creative Commons Attribution 4.0 International License, which permits use, sharing, adaptation, distribution and reproduction in any medium or format, as long as you give appropriate credit to the original author(s) and the source, provide a link to the Creative Commons licence, and indicate if changes were made. The images or other third party material in this article are included in the article's Creative Commons licence, unless indicated otherwise in a credit line to the material. If material is not included in the article's Creative Commons licence and your intended use is not permitted by statutory regulation or exceeds the permitted use, you will need to obtain permission directly from the copyright holder. To view a copy of this licence, visit http://creativecommons.org/licenses/by/4.0/.

\section{References}

Allen RG, Pereira LS, Raes D, Smith M (1998) Crop evapotranspirationguidelines for computing crop water requirements. FAO irrigation and drainage paper 56, Rome, Italy

Asfaw E, Suryabhagavan KV, Argaw M (2018) Soil salinity modeling and mapping using remote sensing and GIS: the case of Wonji sugar cane irrigation farm, Ethiopia. J Saudi Soc Agric Sci 17:250-258. https://doi.org/10.1016/j.jssas.2016.05.003

Askri B, Ahmed AT, Abichou T, Bouhlila R (2014) Effects of shallow water table, salinity and frequency of irrigation water on the date palm water use. J Hydrol 513:81-90. https://doi.org/10.1016/j. jhydrol.2014.03.030

Brunone B, Ferrante M, Romano N, Santini A (2003) Numerical simulations of one-dimensional infiltration into layered soils with the Richards equation using different estimates of the interlayer conductivity. Vadose Zone J 2:193-200. https://doi.org/10.2136/vzj2003. 1930

Chen L, Feng Q, Li F, Li C (2015) Simulation of soil water and salt transfer under mulched furrow irrigation with saline water. Geoderma 241-242:87-96. https://doi.org/10.1016/j.geoderma. 2014.11.007

Chen S, Mao X, Barry DA, Yang J (2019) Model of crop growth, water flow, and solute transport in layered soil. Agric Water Manag 221: 160-174. https://doi.org/10.1016/j.agwat.2019.04.031

Cheng X, Huang M, Si BC, Yu M, Shao M (2013) The differences of water balance components of Caragana korshinkii grown in homogeneous and layered soils in the desert-Loess Plateau transition zone. J Arid Environ 98:10-19. https://doi.org/10.1016/j.jaridenv. 2013.07.007

Feddes RA, Kowalik PJ, Zaradny H (1978) Simulation of field water use and crop yield. Centre for Agricultural Publishing and Documentation, Wageningen

Gao X, Bai Y, Huo Z, Xu X, Huang G, Xia Y, Steenhuis TS (2017) Deficit irrigation enhances contribution of shallow groundwater to crop water consumption in arid area. Agric Water Manag 185:116-125. https://doi.org/10.1016/j.agwat.2017.02.012 
Ghamarnia H, Jalili Z (2014) Shallow saline groundwater use by black cumin (Nigella sativa L.) in the presence of surface water in a semiarid region. Agric Water Manag 132:89-100. https://doi.org/10. 1016/j.agwat.2013.10.012

Grossman RB, Reinsch TG (2002) Bulk density and linear extensibility: core method. In: Dane JH, Topp GC (eds) Methods of soil analysis part 4. Physical methods. Madison: Soil Science Society of America, pp 201-228

He Y, Hu K, Wang H, Huang Y, Chen D, Li B, Li Y (2013) Modeling of water and nitrogen utilization of layered soil profiles under a wheatmaize cropping system. Math Comput Model 58(3-4):596-605. https://doi.org/10.1016/j.mcm.2011.10.060

Huang M, Elshorbagy A, Barbour SL, Zettl JD, Si BC (2011) System dynamics modeling of infiltration and drainage in layered coarse soil. Can J Soil Sci 91(2):185-197. https://doi.org/10.4141/ CJSS10009

Huang M, Bruch PG, Barbour SL (2013) Evaporation and water distribution in layered unsaturated soil profiles. Vadose Zone J 12(1). https://doi.org/10.2136/vzj2012.0108

Ityel E, Lazarovitch N, Silberbush M, Ben-Gal A (2011) An artificial capillary barrier to improve root zone conditions for horticultural crops: physical effects on water content. Irrig Sci 29(2):171-180. https://doi.org/10.1007/s00271-010-0227-3

Ityel E, Lazarovitch N, Silberbush M, Ben-Gal A (2012) An artificial capillary barrier to improve root-zone conditions for horticultural crops: response of pepper, lettuce, melon, and tomato. Irrig Sci 30(4):293-301. https://doi.org/10.1007/s00271-011-0281-5

Jury WA, Horton R (2004) Soil physics, 6th edn. Wiley, New York

Lekakis EH, Antonopoulos VZ (2015) Modeling the effects of different irrigation water salinity on soil water movement, uptake and multicomponent solute transport. J Hydrol 530:431-446. https://doi.org/ 10.1016/j.jhydrol.2015.09.070

Liu BX, Wang SQ, Kong X, Liu XJ (2019) Soil matric potential and salt transport in response to different irrigated lands and soil heterogeneity in the North China plain. J Soils Sediments 19(12):3982-3993. https://doi.org/10.1007/s11368-019-02331-5

Maas EV, Hoffman GJ (1977) Crop salt tolerance-current assessment. J Irrig Drain Div 103(2):115-134

Metternicht GI, Zinck JA (2003) Remote sensing of soil salinity: potentials and constraints. Remote Sens Environ 85:1-20. https://doi.org/ 10.1016/S0034-4257(02)00188-8

Miller DE, Gardner WH (1962) Water infiltration into stratified soil. Soil Sci Soc Am J 26:115-119. https://doi.org/10.2136/sssaj1962. $03615995002600020007 \mathrm{x}$

Mora JL, Herrero J, Weindorf DC (2017) Multivariate analysis of soil salination-desalination in a semi-arid irrigated district of Spain. Geoderma 291:1-10. https://doi.org/10.1016/j.geoderma.2016.12. 018

Moriasi DN, Arnold JG, van Liew MW, Bingner RL, Harmel RD, Veith TL (2007) Model evaluation guidelines for systematic quantification of accuracy in watershed simulations. T ASABE 50(3):885-900. https://doi.org/10.13031/2013.23153

Mualem Y (1976) A new model for predicting the hydraulic conductivity of unsaturated porous media. Water Resour Res 12(3):513-522. https://doi.org/10.1029/WR012i003p00513

Munns R, James RA, Lauchli A (2006) Approaches to increasing the salt tolerance of wheat and other cereals. J Exp Bot 57(5):1025-1043. https://doi.org/10.1093/jxb/erj100

Predelus D, Coutinho AP, Lassabatere L, Bien LB, Winiarski T, AnguloJaramillo R (2015) Combined effect of capillary barrier and layered slope on water, solute and nanoparticle transfer in an unsaturated soil at lysimeter scale. J Contam Hydrol 181(1):69-81. https://doi.org/ 10.1016/j.jconhyd.2015.06.008

Ren L, Huang M (2016) Fine root distributions and water consumption of alfalfa grown in layered soils with different layer thicknesses. Soil Res 54:730-738. https://doi.org/10.1071/SR15126
Ren D, Xu X, Hao Y, Huang G (2016) Modeling and assessing field irrigation water use in a canal system of Hetao, upper Yellow River basin: application to maize, sunflower and watermelon. J Hydrol 532:122-139. https://doi.org/10.1016/j.jhydrol.2015.11.040

Rooney DJ, Brown KW, Thomas JC (1998) The effectiveness of capillary barriers to hydraulically isolate salt contaminated soils. Water Air Soil Pollut 104(3-4):403-411. https://doi.org/10.1023/A: 1004966807950

Schaap MG, Leij FJ, van Genuchten MT (2001) ROSETTA: a computer program for estimating soil hydraulic parameters with hierarchical pedotransfer functions. J Hydrol 251(3-4):163-176. https://doi.org/ 10.1016/S0022-1694(01)00466-8

Shang S, Mao X, Lei Z, Yang S (2009) Models and application of soil water dynamics. Science Press, Beijing

Shi X, Yu D, Warner ED, Pan X, Petersen GW, Gong Z, Weindorf DC (2004) Soil database of 1:1,000,000 digital soil survey and reference system of the Chinese Genetic Soil Classification System. Soil Surv Horiz 45(4):129-136. https://doi.org/10.2136/sh2004.4.0129

Shi W, Shen B, Wang Z, Zhang J (2005) Water and salt transport in sandlayered soil under evaporation with the shallow under ground water table. Transactions of the CSAE 21(9): 23-26 (in Chinese with English abstract). 1002-6819(2005)09-0023-04

Si BC, Dyck M, Parkin GW (2011) Flow and transport in layered soils. Can J Soil Sci 91(2):127-132. https://doi.org/10.1139/CJSS11501

Simunek J, van Genuchten MTh, Sejna M (2005) The HYDRUS-1D software package for simulating the one-dimensional movement of water, heat, and multiple solutes in variably-saturated media version 4.0. Department of Environmental Sciences, University of California Riverside, California

Szymkiewicz A, Helmig R (2011) Comparison of conductivity averaging methods for one-dimensional unsaturated flow in layered soils. Adv Water Resour 34:1012-1025. https://doi.org/10.1016/j.advwatres. 2011.05.011

van Dam JC, Huygen J, Wesseling JG, Feddes RA, Kabat P, van Walsum PEV, Groenendijk P, van Diepen CA (1997) Theory of SWAP version 2.0. Simulation of water flow, solute transport and plant growth in the soil-water-atmosphere-plant environment. Report 71, sub Department of Water Resources, Wageningen University, technical document 45. Alterra Green World Research, Wageningen, the Netherlands

van Genuchten MT (1980) A closed-form equation for predicting the hydraulic conductivity of unsaturated soils. Soil Sci Soc Am J 44(5):892-898. https://doi.org/10.2136/sssaj 1980 . $03615995004400050002 x$

Wang X, Liu G, Yang J, Huang G, Yao R (2017) Evaluating the effects of irrigation water salinity on water movement, crop yield and water use efficiency by means of a coupled hydrologic/crop growth model. Agric Water Manag 185:13-26. https://doi.org/10.1016/j.agwat. 2017.01.012

Wehr JB, So HB, Menzies NW, Fulton I (2005) Hydraulic properties of layered soils influence survival of Rhodes grass (Chloris gayana Kunth.) during water stress. Plant Soil 270(1):287-297. https://doi. org/10.1007/s11104-004-1651-z

Wesseling JG, Elbers JA, Kabat P, van den Broek BJ (1991) SWATRE: instructions for input, internal note. Winand Staring Centre, Wageningen

Williams JR, Jones CA, Kiniry JR, Spanel DA (1989) The EPIC crop growth model. T ASABE 32(2):497-511. https://doi.org/10.13031/ 2013.31032

Wit KE (1967) Apparatus for measuring hydraulic conductivity of undisturbed soil samples. Technical Bulletin 52. Institute for Land and Water Management Research, Wageningen, Netherlands

Xu X, Huang G, Sun C, Pereira LS, Ramos TB, Huang Q, Hao Y (2013) Assessing the effects of water table depth on water use, soil salinity and wheat yield: searching for a target depth for irrigated areas in the 
upper Yellow River basin. Agric Water Manag 125:46-60. https:// doi.org/10.1016/j.agwat.2013.04.004

Xu X, Sun C, Qu Z, Huang Q, Ramos TB, Huang G (2015) Groundwater recharge and capillary rise in irrigation areas of the upper Yellow River Basin assessed by an agro-hydrological model. Irrig Drain 64(5):587-599. https://doi.org/10.1002/ird.1928

Xu X, Sun C, Huang G, Mohanty BP (2016) Global sensitivity analysis and calibration of parameters for a physically-based agro-hydrological model. Environ Model Softw 83:88-102. https://doi.org/10. 1016/j.envsoft.2016.05.013

Xu X, Sun C, Neng F, Fu J, Huang G (2018) AHC: an integrated numerical model for simulating agroecosystem processes-model description and application. Ecol Model 390:23-39. https://doi. org/10.1016/j.ecolmodel.2018.10.015

Zettl JD, Barbour SL, Huang M, Si BC, Leskiw LA (2011) Influence of textural layering on field capacity of coarse soils. Can J Soil Sci 91(2):133-147. https://doi.org/10.4141/cjss09117

Zhou J, Cheng G, Li X, Hu BX, Wang G (2012) Numerical modeling of wheat irrigation using coupled HYDRUS and WOFOST models. Soil Sci Soc Am J 76(2):648-662. https://doi.org/10.2136/ sssaj2010.0467

Publisher's note Springer Nature remains neutral with regard to jurisdictional claims in published maps and institutional affiliations. 